\title{
Antioxidant Activities Estimated by Different Measurments and Inhibitory Potential against Angiotensin I - Converting Enzyme of Protein Hydrolysates from Tea (Camellia sinensis L.) Seed Cake
}

\author{
Qianfei Huang ${ }^{1}$, Limin Mao ${ }^{1,2}$, Le Ying ${ }^{1}$, Yuefei Wang ${ }^{1}$, Ping Xu ${ }^{1, *}$ \\ ${ }^{1}$ Department of Tea Science, Zhejiang University, 866 Yuhangtang Road, Hangzhou, China \\ ${ }^{2}$ Zhejiang Tea Science Society, Hangzhou, China \\ *Corresponding author: zdxp@zju.edu.cn
}

Received February 10, 2015; Revised March 02, 2015; Accepted March 10, 2015

\begin{abstract}
In the present study, protein hydrolysates derived from tea (Camellia sinensis L.) seed cake were prepared by using five different enzymes (alkaline protease, papain, trypsin, flavourzyme and neutral protease). The antioxidant activities and inhibition on angiotensin I-converting enzyme (ACE) of the protein hydrolysates were evaluated in vitro. The results showed that hydrolysates derived from tea seed cake had remarkable antioxidant activities and inhibitory potential against ACE in vitro. Pearson correlation analysis indicated that the antioxidant capacity and ACE inhibitory activity of the hydrolysates might be mainly due to the kind of the enzyme used, not to the degree of hydrolysis (DH) of hydrolysates.
\end{abstract}

Keywords: tea seed cake, antioxidant activity, ACE, protein hydrolysates

Cite This Article: Qianfei Huang, Limin Mao, Le Ying, Yuefei Wang, and Ping Xu, “Antioxidant Activities Estimated by Different Measurments and Inhibitory Potential against Angiotensin I - Converting Enzyme of Protein Hydrolysates from Tea (Camellia sinensis L.) Seed Cake.” Journal of Food and Nutrition Research, vol. 3, no. 3 (2015): 169-175. doi: 10.12691/jfnr-3-3-7.

\section{Introduction}

Free radicals are not only closely associated with lipid peroxidation, but also involved in the development of a variety of diseases. It is recognized that excessive free radicals in human body that may induce damage to cell structures, DNA, lipids and proteins [1], leading to a variety of diseases such as cancers, cardiovascular disease, diabetes, neurological disorders and atherosclerosis [2]. In the past years, natural antioxidants have received considerable attention due to their ability to prevent human body against oxidative stress induced by imbalance between generation and removal of reactive oxygen species and retard the progress of many chronic diseases [3].

Bioactive peptides are regarded as specific protein fragments which are inactive in the parent protein sequence. They can exert several physiological functions after they are released by enzymatic hydrolysis. Previously, several enzyme-hydrolysed proteins from plant and animal sources, such as skin of sole and squid [4], soy [5], chickpea [6], milk porcine and beef muscle [7], were highlighted by their remarkable antioxidant capacity and potent inhibition on angiotensin I-converting enzyme (ACE), which is a key enzyme in the regulation of blood pressure [8], and could be developed as natural antioxidants and potential ACE inhibitors.

Tea (Camellia sinensis L.) seed cake is the main byproduct during the manufacture of tea seed oil, which has long been recognized as an edible oil of high quality. As a consequence of the increase in popularity of tea seed oil, the amount of tea seed cake produced has also increased. Till now, tea seed cake is not typically utilized except being used as cheap fertilizer. Recently, some attention has been put on the active components, such as phenols and glycosides in tea seed cake [9]. However, to the best of our knowledge, few studies have focused on protein hydrolyzates from tea seed cake as far.

Therefore, the aims of this study were to extract protein from tea seed cake and prepare protein hydrolyzates by different enzymes, and to evaluate their antioxidant activity and inhibitory capability on ACE in vitro.

\section{Materials and Methods}

\subsection{Materials}

Tea seed cake was purchased from the Zhejiang Taigu Agricultural Science and Technology Co., Ltd. (Zhejiang, China). Alkaline, flavourzyme, neutral were purchased from Yuanye Biological Technology Co., Ltd. (Shanghai, China). Papain, trypsin, angiotensin converting enzyme 
(ACE) from rabbit lung, hipouril histidine leucine (HHL), 1,1-diphenyl-2-picrylhydrazyl (DPPH), 2,2'-azinobis(3ethylbenzothiazoline-6-sulfonic acid) diammonium salt (ABTS), 2,4,6-tripyridyl-s-triazine (TPTZ) were purchased from Sigma Chemical Co. (Missouri, USA). Ninhydrin was purchased from Aladdin Reagent Co., Ltd. (Shanghai, China). Bovine serum albumin (BSA) was purchased from Sangon Biotech Co., Ltd. (Shanghai, China). All other chemicals were analytical grade and purchased from Sinopharm Chemical Reagent Co. (Shanghai, China).

\subsection{Extraction of Protein from Tea Seed Cake}

Tea seed cake protein was extracted from tea seed cake sing a method developed by Zhong et al. (2007) [5] with slight modification. Tea seed cake was mixed with nhexane at a ratio of $1: 5(\mathrm{w} / \mathrm{v})$, placed at $40^{\circ} \mathrm{C}$ for $2 \mathrm{~h}$ in a water bath. The precipitate was collected after centrifugation at $6000 \times \mathrm{g}$ for $6 \mathrm{~min}$. The above operations were twice repeated. The degreased tea seed meal was mixed with ethanol at a ratio of 1:10 (w/v) and placed at $40^{\circ} \mathrm{C}$ for $2 \mathrm{~h}$ in a water bath. The precipitate, after standing, was collected after centrifugation at $6000 \times \mathrm{g}$ for $6 \mathrm{~min}$. The above operations were twice repeated. The processed tea seed meal was placed on ventilators at $20^{\circ} \mathrm{C}$ for $24 \mathrm{~h}$.

The comminuted tea seed cake was mixed with water at a ratio of $1: 10(\mathrm{w} / \mathrm{v})$ at room temperature. The solution $\mathrm{pH}$ was adjusted to 8.5 with $1 \mathrm{M} \mathrm{NaOH}$ and stirred for $1 \mathrm{~h}$, the mixture was centrifuged $15 \mathrm{~min}$ at $8000 \times \mathrm{g}$ for $15 \mathrm{~min}$, then adjusted to $\mathrm{pH} 5.0$ with $1 \mathrm{M} \mathrm{HCl}$ and stood for $1 \mathrm{~h}$. The obtained precipitate was centrifuged $(8000 \times \mathrm{g}$ for 15 min) and again dissolved with a small amount of distilled water. The supernatant, previously adjusted to $\mathrm{pH} 7.0$, was lyophilized and stored at $20^{\circ} \mathrm{C}$ until use

\subsection{Determination of Protein and Amino Acid Content}

The protein content was determined by the Bradford method [10].

The amino acid content was determined by Nihydrin Colorimetry [11]. One $\mathrm{ml}$ of tea seed cake protein (1 $\mathrm{mg} / \mathrm{ml}$ ) was placed in a $25 \mathrm{ml}$-capacity volumetric flask, added $0.5 \mathrm{ml}$ of phosphate buffer ( $\mathrm{pH} 8.04)$ and $0.5 \mathrm{ml}$ of $2 \%$ solution ninhydrin. The mixture were heated in boiling water for $15 \mathrm{~min}$, then cooled and added to $25 \mathrm{ml}$, finally determined at $570 \mathrm{~nm}$.

\subsection{Protease Hydrolysis of Tea Seed Cake Protein}

Five enzymes, Alkaline, Papain, Trypsin, Flavourzyme and Neutral were used to prepare hydrolysate of the extracted protein from tea seed cake. Various conditions based on the working temperature and $\mathrm{pH}$ [12] of the enzymes were used (Table 1). The protein was dissolved in buffer with specific $\mathrm{pH}$ at $1 \%(\mathrm{w} / \mathrm{v})(10 \mathrm{mg} / \mathrm{ml})$ and then was stood at $90^{\circ} \mathrm{C}$ for $10 \mathrm{~min}$ in a water bath. The protein was hydrolyzed by the individual enzyme at a concentration of $5000 \mathrm{u} / \mathrm{g}$ protein. The enzymatic hydrolysis was stood at different temperature for $4 \mathrm{~h}$. The enzymatic reactions were terminated by boiling for $5 \mathrm{~min}$.
Each mixture was adjusted to $\mathrm{pH} 7.0$ and centrifuged at $7000 \times \mathrm{g}$ for $10 \mathrm{~min}$. The supernatant was freeze-dried and stored at $-20^{\circ} \mathrm{C}$.

\subsection{Determination of the Degree of Hydrolysis (DH)}

The degree of hydrolysis (DH) of tea seed cake hydrolysates was determined according to ninhydrin colormetry [13] with tiny modification. Supernatant $(0.2$ $\mathrm{ml}$ ) of tea seed cake hydrolysates was placed into a 100ml-capacity volumetric flask, distilled water was added up to $100 \mathrm{ml}$. $1 \mathrm{ml}$ of sample, $1 \mathrm{ml}$ of water, $3 \mathrm{ml}$ of ninhydrin solution ( $0.4 \mathrm{~g}$ of ninhydrin, $5 \mathrm{ml}$ of n-propanol, $10 \mathrm{ml}$ of n-butyl alcohol, $20 \mathrm{ml}$ of ethylene glycol and 3 $\mathrm{ml}$ of $\mathrm{pH} 4.5$ acetic acid buffer), and $0.1 \mathrm{ml}$ of $1 \%$ (w/w) ascorbic acid were mixed. The mixture was heated in boiling water for $15 \mathrm{~min}$ and then shook and cooled shook to room temperature by cold water.-Ethanol solution (60\% $\mathrm{v} / \mathrm{v}$ ) was added to make sure that the total volume of the mixture was $5 \mathrm{ml}$. The absorbance of the mixture was read at $580 \mathrm{~nm}$, and distilled water was used to calibrate. The degree of hydrolysis (DH) was calculated as follows:

$$
\mathrm{DH}(\%)=\left(\mathrm{A}_{1}-\mathrm{A}_{2}\right) /\left(\mathrm{A}_{3}-\mathrm{A}_{2}\right) \times 100
$$

$\mathrm{A}_{1}$ : supernatant of tea seed cake hydrolysates;

$\mathrm{A}_{2}$ : crude protein from tea seed cake;

$\mathrm{A}_{3}$ : tea seed cake protein hydrolyzed by $6 \mathrm{M} \mathrm{HCl}$ at $110^{\circ} \mathrm{C}$ for $24 \mathrm{~h}$.

\subsection{In Vitro Antioxidant Capacity}

\subsubsection{DPPH Radical Scavenging}

The DPPH free radical scavenging activity of the tea seed cake protein hydrolysates was determined by the method of Mohsen et al. [14], with a slight modification. One milliliter of the tested samples at various concentrations $(156.25-10000 \mu \mathrm{g} / \mathrm{ml})$ was added to $3 \mathrm{ml}$ of ethanolic DPPH solutions $(0.1 \mathrm{mM})$. The reaction mixture was incubated for $30 \mathrm{~min}$ in the darkness at room temperature. The increasing of absorbance was measured at $517 \mathrm{~nm}$. The DPPH scavenging effect was calculated as follows:

$$
\text { DPPH scavenging effect }(\%)=\left(1-\mathrm{A}_{\text {samp }} / \mathrm{A}_{\text {cont }}\right) \times 100
$$

where $\mathrm{A}_{\text {samp }}$ and $\mathrm{A}_{\text {cont }}$ are defined as absorbance of the sample and the control, respectively.

\subsubsection{ABTS Radical Scavenging}

ABTS assay was carried out according to the method of Cai et al. (2004) [15]. The ABTS cation radical solution was prepared by mixing $7 \mathrm{mM}$ ABTS and $2.45 \mathrm{mM}$ potassium persulfate and incubating in the dark at room temperature for $12 \mathrm{~h}$. The ABTS cation radical solution was then diluted with water to obtain an absorbance of $0.70 \pm 0.02$ at $734 \mathrm{~nm}$. ABTS cation radical solution ( $3 \mathrm{ml})$ was added to $0.1 \mathrm{ml}$ of the test samples with various concentrations (156.25-10000 $\mu \mathrm{g} / \mathrm{ml}$ ) and vigorously mixed. The absorbance was measured at $734 \mathrm{~nm}$ after standing for $6 \mathrm{~min}$. The ABTS scavenging effect was calculated as follows: 
ABTS scavenging effect $(\%)=\left(1-\mathrm{A}_{\text {samp }} / \mathrm{A}_{\text {cont }}\right) \times 100$

where $\mathrm{A}_{\text {samp }}$ and $\mathrm{A}_{\text {cont }}$ are defined as absorbance of the sample and the control, respectively.

\subsubsection{Ferric Reducing Antioxidant Power (FRAP)}

The ferric-reducing antioxidant power (FRAP) assay was performed according to a modified method of Benzie et al., (1999) [16]. Briefly, the working FRAP reagent was prepared by mixing $10 \mathrm{vol}$ of $300 \mathrm{mM}$ acetate buffer ( $\mathrm{pH}$ 3.6) with 1 vol of TPTZ $(10 \mathrm{mM})$ in $\mathrm{HCl}(40 \mathrm{mM})$ and with 1 vol of $\mathrm{FeCl}_{3}(20 \mathrm{mM})$. Freshly prepared FRAP reagent was warmed at $37^{\circ} \mathrm{C}$, and a reagent blank reading was taken at $593 \mathrm{~nm}$. Subsequently, $0.6 \mathrm{ml}$ of test samples with various concentrations (156.25 $-10000 \mu \mathrm{g} / \mathrm{ml})$ was added to the FRAP reagent $(4.5 \mathrm{ml})$. A second reading at $593 \mathrm{~nm}$ was performed after $8 \mathrm{~min}$. The initial blank reading with the FRAP reagent alone was subtracted from the final reading of the FRAP reagent with the sample to determine the FRAP value of the sample. A standard curve was prepared using different concentrations (25 $1500 \mu \mathrm{M})$ of $\mathrm{FeSO}_{4} \cdot 7 \mathrm{H}_{2} \mathrm{O}$. The reducing ability of the samples were expressed as the equivalent to that of $1 \mu \mathrm{M}$ $\mathrm{FeSO}_{4} \cdot 7 \mathrm{H}_{2} \mathrm{O}$.

\subsection{In Vitro ACE Inhibitory Activity}

ACE inhibition was performed by the method of Nakamura et al., (1995) [17] with a slight modification. In brief, $20 \mu \mathrm{l}$ of sample and $120 \mu \mathrm{l}$ of hippuryl-L-histidyl-Lleucine (HHL, $5 \mathrm{mM}$ in $0.1 \mathrm{M}$ sodium borate buffer containing $\mathrm{NaCl} 0.3 \mathrm{M}, \mathrm{pH} 8.3$ ) were incubated at $37^{\circ} \mathrm{C}$ for $5 \mathrm{~min}$. Then, $150 \mu \mathrm{l}$ of ACE was added and the mixture was incubated for an hour at $37^{\circ} \mathrm{C}$. Sample blanks (inactivating the enzyme at first) and a blank (buffer instead of sample) were also included. The enzymatic reaction was stopped by adding $150 \mu \mathrm{l}$ of $1 \mathrm{M} \mathrm{HCl}$. The hippuric acid formed by the action of the ACE on HHL, was extracted from the acidified solution into $1 \mathrm{ml}$ ethyl acetate by stirring for $15 \mathrm{~s}$. The mixture was centrifuged at $4000 \times g$ for $10 \mathrm{~min}$, and a $750 \mu$ aliquot of each ethyl acetate layer was transferred to clean tubes and evaporated by heating at $120^{\circ} \mathrm{C}$ in an oven. The hippuric acid was redissolved in $3 \mathrm{ml}$ of water, and the absorbance was measured at $228 \mathrm{~nm}$ after $0.5 \mathrm{~min}$.

\subsection{Statistical Analysis}

All the experiments were carried out in triplicate. The results were expressed as means $\pm \mathrm{SD}$ and evaluated by analysis of variance (ANOVA) followed by Turkey's studentized range test carried out on the SAS system for windows V9 (Version 9.1, SAS Institute Inc., Cary, NC, USA), and $p<0.05$ was regarded as statistically significant. Pearson's correlation coefficients were determined by SPSS (version 16.0). $\mathrm{EC}_{50}$ values were calculated by curve fitting using OriginPro (version 8.0).

\section{Results}

\subsection{Chemical Compositions}

In this study, the yield of protein from tea seed cake was $2.62 \%$. Meanwhile, the contents of protein and amino acid in the extract of tea seed cake were $53.37 \pm 6.62$ and $20.52 \pm 0.75 \%$, respectively.

\subsection{Degree of Hydrolysis (DH) of Enzymatic Hydrolysates}

The enzymatic hydrolysis was prepared by varied condition according to the five proteases (Table 1). As shown in Figure 1, the highest DH was $25.71 \%$, which was found in papain hydrolysate, followed by that of neutral $(12.11 \%)$. The hydrolysis capacity of alkaline and flavourzyme to tea seed protein seemed to be similar, where, the $\mathrm{DH}$ of the hydrolysates by them were $10.68 \%$ and $10.87 \%$, respectively.

Table 1. The optimum hydrolysis condition of enzymes

\begin{tabular}{ccc}
\hline Protease type & $\mathrm{pH}$ & Temperature $\left({ }^{\circ} \mathrm{C}\right)$ \\
\hline Alkaline & 8.0 & 55 \\
Papain & 6.5 & 55 \\
Trypsin & 8.0 & 37 \\
Flavourzyme & 7.0 & 50 \\
Neutral & 7.0 & 50 \\
\hline
\end{tabular}

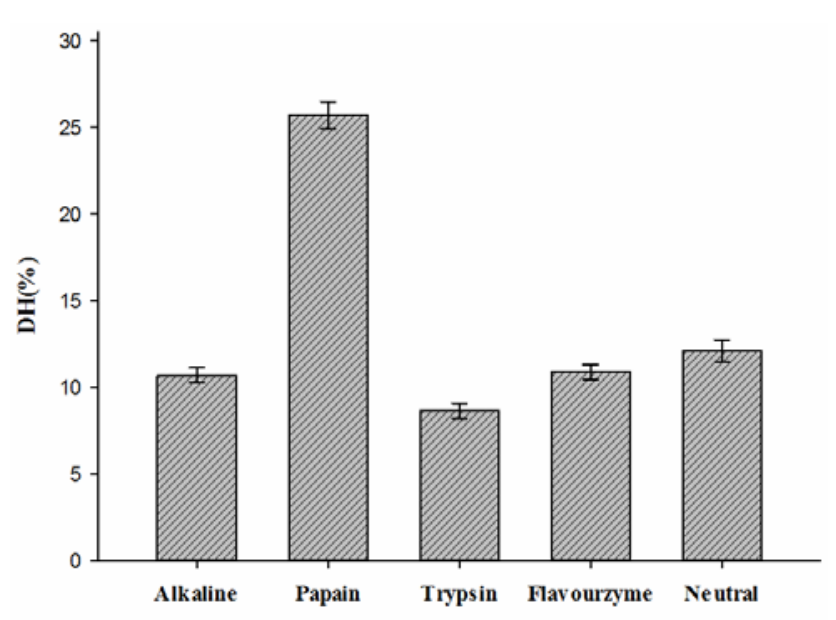

Figure 1. The DH of five hydrolysis of tea seed cake protein by five enzymes. Alkaline, papain, trypsin, flavourzyme and neutral are the tea seed cake protein hydrolysates hydrolyzed by alkaline, papain, trypsin and flavourzyme and neutral and respectively

\subsection{Antioxidant Properties}

\subsubsection{DPPH Radical Scavenging Activity}

DPPH is one kind of relatively stable free radicals with unpaired electron and DPPH free radical assay were used to test the free radical scavenging activity of the hydrolysates. As shown in Figure 2, all hydrolysates showed a concentration-dependent effect on scavenging ability DHHP radical. In the tested concentration range, the order of scavenging ability was alkaline > 
flavourzyme $>$ neutral $>$ papain $>$ trypsin with $\mathrm{EC}_{50}$ $(\mathrm{mg} / \mathrm{ml})$ of $1.65,2.17,2.23,2.74,3.82$, respectively (Table 2).

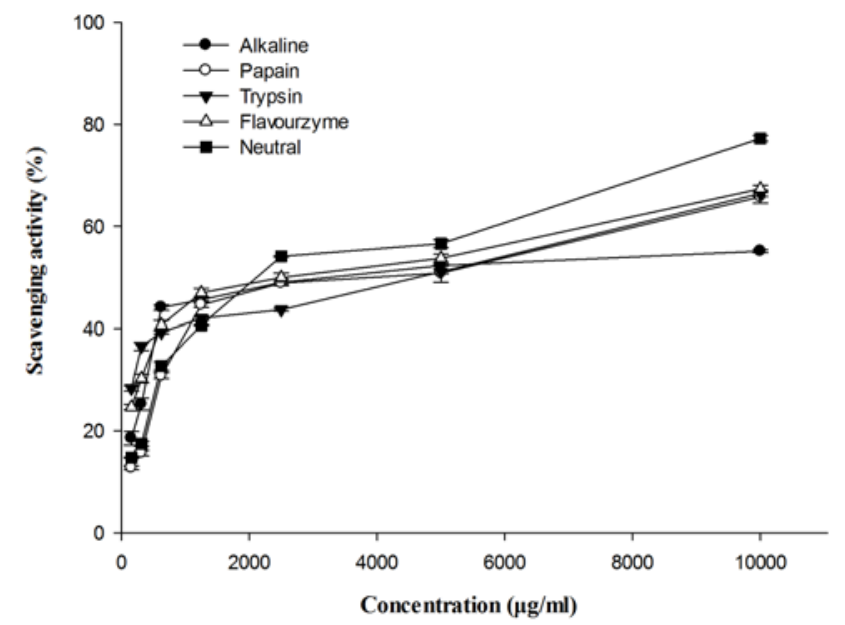

Figure 2. DPPH radical scavenging activity of tea seed cake protein hydrolysis. Alkaline, papain, trypsin, flavourzyme, and neutral are the tea seed cake protein hydrolysates hydrolyzed by alkaline, papain, trypsin, flavourzyme and neutral, respectively

\subsubsection{ABTS Radical Scavenging Activity}

The ABTS radical scavenging activity of five protein hydrolysates was shown in Figure 3. It can be observed that all these hydrolysates showed a concentrationdependent scavenging activity on ABTS radical. The scavenging ability of the hydrolysates on ABTS radical was in the following order: flavourzyme $>$ trypsin $>$ alkaline $>$ neutral $>$ papain with $\mathrm{EC}_{50}(\mathrm{mg} / \mathrm{ml})$ of 1.89, 2.23, 2.14, 2.37, 3.39, respectively (Table 2).

Table 2. Effective concentrations of the antioxidant and ACE inhibitory activities of the tea seed cake protein hydrolysis

\begin{tabular}{ccccc}
\hline & $\begin{array}{c}\mathrm{DPPH} \\
(\mathrm{EC} 50, \\
\mathrm{mg} / \mathrm{ml})\end{array}$ & $\begin{array}{c}\text { ABTS } \\
\left(\mathrm{EC}_{50},\right. \\
\mathrm{mg} / \mathrm{ml})\end{array}$ & $\begin{array}{c}\mathrm{FRAP} \\
(\mu \mathrm{mol} / \mathrm{L}) \\
(5000 \\
\mu \mathrm{g} / \mathrm{ml})\end{array}$ & $\begin{array}{c}\mathrm{ACE} \\
\left(\mathrm{EC}_{30},\right. \\
\mathrm{mg} / \mathrm{ml})\end{array}$ \\
\hline Alkaline & 1.65 & 2.14 & 199.82 & 0.65 \\
Papain & 2.74 & 3.39 & 144.65 & 0.65 \\
Trypsin & 3.82 & 2.23 & 165.82 & 0.71 \\
Flavourzyme & 2.17 & 1.89 & 216.38 & 1.15 \\
Neutral & 2.23 & 2.37 & 243.14 & 0.17 \\
\hline
\end{tabular}

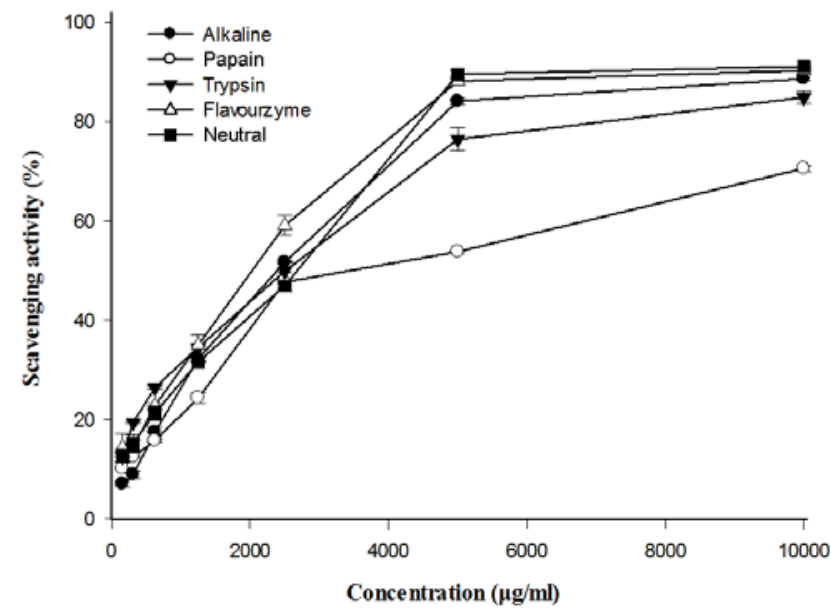

Figure 3. ABTS radical scavenging activity of tea seed cake protein hydrolysis. Alkaline, papain, trypsin, flavourzyme, and neutral are the tea seed cake protein hydrolysates hydrolyzed by alkaline, papain, trypsin, flavourzyme and neutral, respectively

\subsubsection{Reducing Activity}

The results of FRAP assay were sown in Figure 4. The ferric-reducing power of these protein hydrolysates exhibited a significant concentration-dependent effect. The order of reducing activity of these five hydrolysates was as follows neutral $>$ flavourzyme $>$ alkaline $>$ trypsin $>$ papain at a concentration of $5000 \mu \mathrm{g} / \mathrm{ml}$.

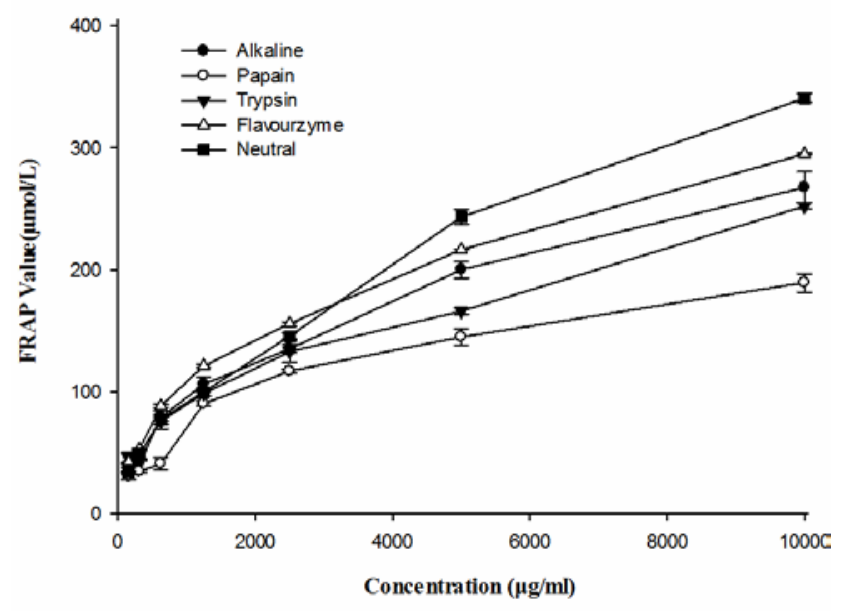

Figure 4. Ferric-reducing antioxidant power (FRAP) ability of tea seed cake protein hydrolysis. Alkaline, papain, trypsin, flavourzyme and neutral are the tea seed cake protein hydrolysates hydrolyzed by alkaline, papain, trypsin, flavourzyme and neutral, respectively

\subsection{ACE Inhibitory Activity}

The inhibitory activity on ACE of five hydrolysates was presented in Figure 5. As shown, the ACE inhibitory activity of neutral hydrolysates increased from $24.00 \%$ to $58.16 \%$ with the concentration from $125 \mu \mathrm{g} / \mathrm{ml}$ to 4000 $\mu \mathrm{g} / \mathrm{ml}$. The order of reducing activity of these five hydrolysates was as follows neutral $>$ alkaline= papain $>$ trypsin $>$ flavourzyme with $\mathrm{EC}_{30}(\mathrm{mg} / \mathrm{ml})$ of $0.17,0.65$, $0.65,0.71,1.15$, respectively (Table 2 ).

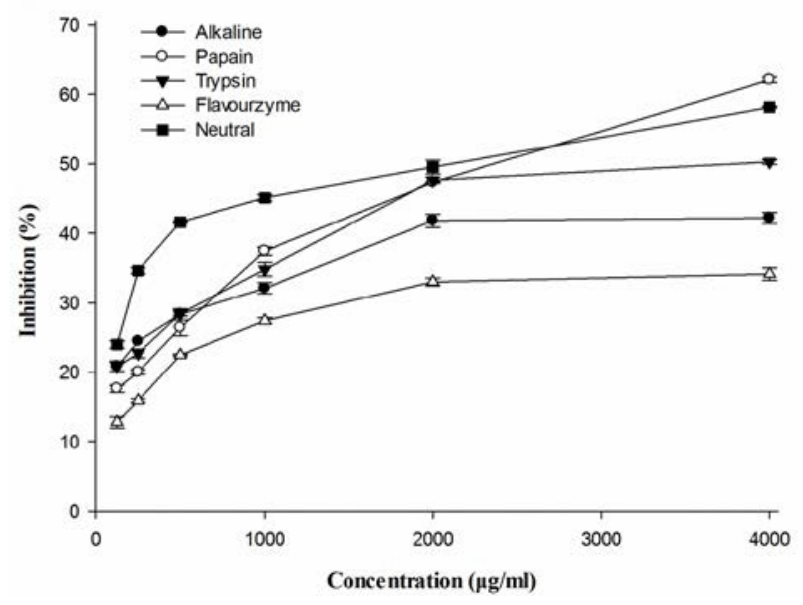

Figure 5. ACE inhibitory activities of tea seed cake protein hydrolysis. Alkaline, papain, trypsin, flavourzyme and neutral are the tea seed cake protein hydrolysates hydrolyzed by alkaline, papain, trypsin, flavourzyme and neutral, respectively 


\section{Discussion}

Protein is regarded as a source of energy and essential amino acids, which plays an important role in the growth, metabolism and maintenance of physiological functions [18]. Recent studies focused on the bioactive peptides, exhibited various physiological functions, derived from animal and plant protein [19], and indicated that such protein hydrolysates could be safe and effective agents with some advantages in comparison to protein. Specially, the utilization of the wastes or by-products for such agents has been recently attracting lots of attention. In this study, protein hydrolysates were prepared from tea seed cake, the main by-product during tea (Camellia sinensis L.) seed oil production. China is the world's largest tea producing and exporting country and also a big tea consumer. Over 1000 million kg of tea fruit are produced annually in China [20]. Many studies have shown that tea seed oil has several health benefits for human beings as the tea seed oil contains more than $84 \%$ unsaturated fatty acid, such as oleic acid (62.5\% by weight), linoleic acid (18.1\% by weight) and linolenic acid [21]. Increasing amounts of tea seed cake have been produced as the byproducts during the manufacture of tea seed oil, which was recognized by the Ministry of Health, China, as a new food resource in 2009. The extraction rate of tea seed oil is about $14-15 \%$ and after expelling the rest, except tea seed peel, is mainly tea seed cake so there is large amount of tea seed cake in this industry. In addition, the extraction method showed above of tea seed cake protein hydrolysates is simple, feasible and non-toxic. The article suggests that utilizing this readily available and low cost resource can brings both economic and environmental interest.

A vast number of evidence has implicated that oxidative stress was associated with a wide range of diseases [22]. Lots of studies have shown the peptides have inhibitions on lipid peroxidation [23,24], scavengers of free radicals [25,26] and chelators of transition metalions [26,27] (In the present study, DPPH, ABTS and FRAP assays were used to evaluate the antioxidant activity of the protein hydrolysates from tea seed cake, respectively. DPPH free radical is capable of accepting an electron or a hydrogen radical to become a stable diamagnetic molecule [28], and it has been widely used to test the free radical scavenging ability of various natural products $[29,30]$, ABTS cation radicals are more reactive than DPPH radicals and unlike the reactions with DPPH radicals, which involve $\mathrm{H}$ atom transfer, the reactions with ABTS cation radicals involve an electron transfer process [31]. Moreover, The FRAP assay is based on a redox reaction where a ferric $\left(\mathrm{Fe}^{3+}\right)$ complex is reduced to the blue ferrous $\left(\mathrm{Fe}^{2+}\right)$ form by oxidation of a reductant (antioxidant) [16]. FRAP measures is alternatively considered as the ability of a natural antioxidant to donate electrons [32]. By calculating $\mathrm{EC}_{50}$ (Table 2), it was found that protein hydrolysates had inconsistent performance in varied systems, which may attributed to the different mechanisms as discussed above, and to the composition and the sequence of amino acid of hydrolysates as well. In literature, Tyr, Trp, Met, Lys, Cys, and His are examples of amino acids that have antioxidant activity [33]. However, the exact mechanism underlying the antioxidant activity of peptides has not been fully understood yet.
Hypertension is one of the top five most common diseases in the world and over $25 \%$ of the adult populations nearly one billion in 2000 were affected by hypertension [34]. ACE plays an important physiological role in the regulation of blood pressure by virtue of the rennin angiotensin system. ACE also inactivates the vasodilative peptide bradykinin in the kallikrein-kinin system [35]. Additionally, ACE functions as a stimulant for the release of aldosterone in the adrenal cortex [36]. Therefore Inhibition of ACE is considered to be a widely used and effective approach in the treatment of hypertension. ACE inhibitors have been developed as antihypertensive medicine, but such synthetic chemical inhibitors can cause serious side effects [37]. The search for natural alternatives has resulted in the identification of numerous ACE inhibitory peptides derived from various sources. In our study, all these protein hydrolysates had ACE inhibitory activity, and the $\mathrm{EC}_{30}$ values for ACE inhibition of all hydrolysates varied between 0.17 and $1.15 \mathrm{mg} / \mathrm{ml}$ (Table 2). Meanwhile, ACE inhibitory activity of hydrolysates derived from oyster, scallop, codfish skin, and codfish bone has been already reported, and the $\mathrm{IC}_{50}$ of most of them was higher than $10 \mathrm{mg} / \mathrm{ml}$ [38]. Saiga et al., (2003) [27] demonstrated that a disparity in activity of two similar hydrolysates (regarding their amino acid compositions) could be related to the structure and length of the peptides in the hydrolysates.

Meanwhile, oxidative stress was suggested to play a very important role in the mechanism of essential hypertension [39]. Oxidative stress was defined as the sustained increase in the levels of reactive oxygen species (ROS), and it has been reported that antioxidant peptides keep cells safe from damage by ROS through the induction of genes [40]. According to Table 3, it was observed that $\mathrm{DH}$ of the hydrolysates had significant $(p<$ 0.05) positive correlation with ABTS radical scavenging capacity, and was not statistically significant $(p>0.05)$ with DPPH radical scavenging, FRAP reducing activity and ACE inhibitory activity. These results may imply that the different antioxidant capacity and ACE inhibitory activity of the hydrolysates was mainly due to the kind of the enzyme used, not to the DH of hydrolysates. Antioxidant activity of protein hydrolysates is affected by amount and composition of free amino acid and peptides [24], the type of protease, degree of hydrolysis [41] as well as size [24], structure, amino acid composition and amino acid sequences of peptides in hydrolysates [42]. Therefore, purification and analysis of the amino acid sequence of the hydrolysates should be carried out in the future.

Table 3. Pearson correlation analysis

\begin{tabular}{cccccc}
\hline & DH & DPPH & ABTS & FRAP & ACE \\
\hline DH & 1.000 & 0.008 & $0.944^{*}$ & -0.563 & -0.094 \\
DPPH & & 1.000 & 0.217 & -0.580 & 0.032 \\
ABTS & & & 1.000 & -0.643 & -0.311 \\
FRAP & & & & 1.000 & -0.257 \\
ACE & & & & & 1.000 \\
\hline${ }^{*}<0.05$ & & & & &
\end{tabular}

${ }^{*} \mathrm{p}<0.05$

\section{Conclusion}

In conclusion, the protein hydrolysates derived from tea seed cake possessed remarkable antioxidant activities and 
inhibitory potential against ACE in vitro, and may have a potential to be used as functional agents, such as antioxidants and ACE inhibitors. Meanwhile, tea seed cake, as worthless by-product, could be developed as cheap, renewable and readily resource for preparation of bioactive peptides. In addition, separation and purification of these protein hydrolysates are required in further researches, and animal models should be employed to validate the bioactivities of them as well.

\section{Acknowledgements}

This work was supported by the Ministry of Science and Technology, China (No. 2012BAD36B06-5) and the Science and Technology Department of Zhejiang Province, China (No. 2010LM201-15) and the Department of Education of Guangdong Province, China (No. 2012B091100165).

\section{References}

[1] Valko, M., Leibfritz, D., Moncol, J., Cronin, M. T., Mazur, M., and Telser, J. "Free radicals and antioxidants in normal physiological functions and human disease," International Journal of Biochemistry and Cell Biology, 39 (1), 44-84, 2007.

[2] Dalle-Donne, I., Rossi, R., Colombo, R., Giustarini, D., and Milzani, A. "Biomarkers of oxidative damage in human disease," Clinical chemistry, 52 (4), 601-623, 2006.

[3] Ozsoy, N., Can, A., Yanardag, R., and Akev, N. "Antioxidant activity of Smilax excelsa L. leaf extracts," Food Chemistry, 110 (3), 571-583, 2008.

[4] Giménez, B., Alemán, A., Montero, P., and Gómez-Guillén, M. "Antioxidant and functional properties of gelatin hydrolysates obtained from skin of sole and squid," Food Chemistry, 114 (3), 976-983, 2009.

[5] Zhong, F., Liu, J., Ma, J., and Shoemaker, C. F. "Preparation of hypocholesterol peptides from soy protein and their hypocholesterolemic effect in mice," Food research international, 40 (6), 661-667, 2007.

[6] Li, Y., Jiang, B., Zhang, T., Mu, W., and Liu, J. "Antioxidant and free radical-scavenging activities of chickpea protein hydrolysate (CPH)," Food Chemistry, 106 (2), 444-450, 2008.

[7] Korhonen, H., and Pihlanto, A. "Bioactive peptides: production and functionality," International Dairy Journal, 16 (9), 945-960, 2006.

[8] Unger, T. "The role of the renin-angiotensin system in the development of cardiovascular disease," The American journal of cardiology, 89 (2A), 3A, 2002.

[9] Li, B., Xu, Y., Jin, Y.-X., Wu, Y.-Y., and Tu, Y.-Y. "Response surface optimization of supercritical fluid extraction of kaempferol glycosides from tea seed cake," Industrial Crops and Products, 32 (2), 123-128, 2010.

[10] Bradford, M. M. "A rapid and sensitive method for the quantitation of microgram quantities of protein utilizing the principle of protein-dye binding," Analytical biochemistry, 72(1), 248-254, 1976.

[11] Sun, S.-W., Lin, Y.-C., Weng, Y.-M., and Chen, M.-J. "Efficiency improvements on ninhydrin method for amino acid quantification," Journal of Food Composition and Analysis, 19 (23), 112-117, 2006.

[12] Gong Ji-jun, L. Z.-h., Zhong Hai-yan, Huang Liang, Zhou Wenhua. "Study on Preparation and Antioxidant Activity of Tea-seed Peptide," Food Research and Development, 10, 59-62, 2007.

[13] Zhang, Y., Zhang, H., Wang, L., Guo, X., Qi, X., and Qian, H. "Influence of the degree of hydrolysis (DH) on antioxidant properties and radical-scavenging activities of peanut peptides prepared from fermented peanut meal," European Food Research and Technology, 232 (6), 941-950, 2011.

[14] Mohsen, S. M., and Ammar, A. S. "Total phenolic contents and antioxidant activity of corn tassel extracts," Food Chemistry, 112 (3), 595-598, 2009.
[15] Cai, Y., Luo, Q., Sun, M., and Corke, H. "Antioxidant activity and phenolic compounds of 112 traditional Chinese medicinal plants associated with anticancer," Life sciences, 74 (17), 2157-2184, 2004.

[16] Benzie, I. F., and Strain, J. "[2] Ferric reducing/antioxidant power assay: Direct measure of total antioxidant activity of biological fluids and modified version for simultaneous measurement of total antioxidant power and ascorbic acid concentration," Methods in enzymology, 299, 15-27, 1999.

[17] Nakamura, Y., Yamamoto, N., Sakai, K., Okubo, A., Yamazaki, S., and Takano, T. "Purification and characterization of angiotensin Iconverting enzyme inhibitors from sour milk," Journal of dairy science, 78 (4), 777-783, 1995.

[18] Voet, D., and Voet, J. G. "Biochemistry. Hoboken," John Wiley \& Sons, 1, 591, 2004.

[19] Hartmann, R., and Meisel, H. "Food-derived peptides with biological activity: from research to food applications," Current Opinion in Biotechnology, 18 (2), 163-169, 2007.

[20] Wang, Y., Huang, S., Shao, S., Qian, L., and Xu, P. "Studies on bioactivities of tea (Camellia sinensis L.) fruit peel extracts: Antioxidant activity and inhibitory potential against $\alpha$-glucosidase and $\alpha$-amylase in vitro," Industrial Crops and Products, 37 (1), 520-526, 2012.

[21] Demirbas, A. "Tea seed upgrading facilities and economic assessment of biodiesel production from tea seed oil," Energy Conversion and Management, 51 (12), 2595-2599, 2010.

[22] Finkel, T., and Holbrook, N. J. "Oxidants, oxidative stress and the biology of ageing," Nature, 408 (6809), 239-247, 2000.

[23] Qian, Z.-J., Jung, W.-K., Byun, H.-G., and Kim, S.-K. "Protective effect of an antioxidative peptide purified from gastrointestinal digests of oyster, Crassostrea gigas against free radical induced DNA damage," Bioresource Technology, 99 (9), 3365-3371, 2008.

[24] Wu, H.-C., Chen, H.-M., and Shiau, C.-Y. "Free amino acids and peptides as related to antioxidant properties in protein hydrolysates of mackerel (Scomber austriasicus)," Food research international, 36 (9), 949-957, 2003.

[25] Qian, Z.-J., Jung, W.-K., and Kim, S.-K. "Free radical scavenging activity of a novel antioxidative peptide purified from hydrolysate of bullfrog skin, Rana catesbeiana Shaw," Bioresource Technology, 99 (6), 1690-1698, 2008.

[26] Rajapakse, N., Mendis, E., Byun, H.-G., and Kim, S.-K. "Purification and in vitro antioxidative effects of giant squid muscle peptides on free radical-mediated oxidative systems," The Journal of nutritional biochemistry, 16 (9), 562-569, 2005.

[27] Saiga, A., Tanabe, S., and Nishimura, T. "Antioxidant activity of peptides obtained from porcine myofibrillar proteins by protease treatment," Journal of Agricultural and Food Chemistry, 51 (12), 3661-3667, 2003.

[28] Soare, J. R., Dinis, T. C., Cunha, A. P., and Almeida, L. "Antioxidant activities of some extracts of Thymus zygis," Free Radical Research, 26 (5), 469-478, 1997.

[29] Giovanelli, G., and Buratti, S. "Comparison of polyphenolic composition and antioxidant activity of wild Italian blueberries and some cultivated varieties," Food Chemistry, 112 (4), 903-908, 2009.

[30] Kuda, T., and Ikemori, T. "Minerals, polysaccharides and antioxidant properties of aqueous solutions obtained from macroalgal beach-casts in the Noto Peninsula, Ishikawa, Japan," Food Chemistry, 112 (3), 575-581, 2009.

[31] Kaviarasan, S., Naik, G., Gangabhagirathi, R., Anuradha, C., and Priyadarsini, K. "In vitro studies on antiradical and antioxidant activities of fenugreek (Trigonella foenum graecum) seeds," Food Chemistry, 103 (1), 31-37, 2007.

[32] Shi, J., Gong, J., Liu, J. e., Wu, X., and Zhang, Y. "Antioxidant capacity of extract from edible flowers of Prunus mume in China and its active components," LWT-Food Science and Technology, 42 (2), 477-482, 2009.

[33] Wang, W., Mejia, D., and Gonzalez, E. "A New Frontier in Soy Bioactive Peptides that May Prevent Age - related Chronic Diseases," Comprehensive reviews in food science and food safety, 4 (4), 63-78, 2005.

[34] Kearney, P. M., Whelton, M., Reynolds, K., Muntner, P., Whelton, P. K., and He, J. "Global burden of hypertension: analysis of worldwide data," Lancet, 365 (9455), 217-223, 2005.

[35] Meisel, H., Walsh, D., Murray, B., FitzGerald, R., Mine, Y., and Shahidi, F. "ACE inhibitory peptides," Nutraceutical proteins and peptides in health and disease, 269-315, 2006. 
[36] Silvestre, J.-S., Heymes, C., Oubénaïssa, A., Robert, V., AupetitFaisant, B., Carayon, A., Swynghedauw, B., and Delcayre, C. "Activation of cardiac aldosterone production in rat myocardial infarction: effect of angiotensin II receptor blockade and role in cardiac fibrosis," Circulation, 99 (20), 2694-2701, 1999.

[37] Antonios, T. F., and MacGregor, G. A. "Angiotensin converting enzyme inhibitors in hypertension: potential problems," Journal of Hypertension, 13, S11, 1995.

[38] He, H.-L., Chen, X.-L., Wu, H., Sun, C.-Y., Zhang, Y.-Z., and Zhou, B.-C. "High throughput and rapid screening of marine protein hydrolysates enriched in peptides with angiotensin-Iconverting enzyme inhibitory activity by capillary electrophoresis," Bioresource Technology, 98 (18), 3499-3505, 2007.

[39] Ghulmiyyah, L. M., Costantine, M. M., Yin, H., Tamayo, E., Clark, S. M., Hankins, G. D., Saade, G. R., and Longo, M. "The role of oxidative stress in the developmental origin of adult hypertension," American journal of obstetrics and gynecology, 205 (2), 155. e157-155. e111, 2011.

[40] Erdmann, K., Grosser, N., Schipporeit, K., and Schröder, H. "The ACE inhibitory dipeptide Met-Tyr diminishes free radical formation in human endothelial cells via induction of heme oxygenase-1 and ferritin," The Journal of nutrition, 136 (8), 21482152, 2006.

[41] Liu, Q., Kong, B., Xiong, Y. L., and Xia, X. "Antioxidant activity and functional properties of porcine plasma protein hydrolysate as influenced by the degree of hydrolysis," Food Chemistry, 118 (2), 403-410, 2010.

[42] Chen, H.-M., Muramoto, K., Yamauchi, F., Fujimoto, K., and Nokihara, K. "Antioxidative properties of histidine-containing peptides designed from peptide fragments found in the digests of a soybean protein," Journal of Agricultural and Food Chemistry, 46 (1), 49-53, 1998. 